\title{
Purification and properties of an acid endo-1,4- $\beta$-glucanase from Bacillus sp. KSM-330
}

\author{
KatsuYa OZaki* and Susumu Ito \\ Tochigi Research Laboratories of Kao Corporation, 2606 Akabane, Ichikai, Tochigi 321-34, Japan
}

(Received 14 August 1990; revised 25 September 1990; accepted 28 September 1990)

\begin{abstract}
A novel acid cellulase (endo-1,4- $\beta$-glucanase, EC 3.2.1.4) was found in a culture of Bacillus $\mathbf{~ s p . ~ K S M - 3 3 0 ~ i s o l a t e d ~}$ from soil. One-step chromatography on a column of CM-Bio-Gel A yielded a homogeneous enzyme, as determined by silver staining of both sodium dodecyl sulphate (SDS) and nondenaturing gels. The enzyme had a molecular mass of $42 \mathrm{kDa}$, as determined by SDS-polyacrylamide gel electrophoresis. The isoelectric point was higher than pH 10. The N-terminal amino acid sequence of the enzyme was Val-Ala-Lys-Glu-Met-Lys-Pro-Phe-Pro-Gln-GlnVal-Asn-Tyr-Ser-Gly-Ile-Leu-Lys-Pro. This enzyme had an optimum pH for activity of 5-2, being active over an extremely narrow range of $\mathrm{pH}$ values, from 4.2 to 6.9; below and above these $\mathrm{pH}$ values no activity was detectable. The optimum temperature at pH 5.2 was around $45^{\circ} \mathrm{C}$. The enzyme efficiently hydrolysed carboxymethylcellulose (CMC) and lichenan, but more crystalline forms of cellulose, curdlan, laminarin, 4-nitrophenyl- $\beta$-Dglucopyranoside and 4-nitrophenyl- $\beta$-D-cellobioside were barely hydrolysed. The enzymic activity was inhibited by $\mathrm{Hg}^{2+}$ but was not affected by other inhibitors of thiol enzymes, such as 4-chloromercuribenzoate, $N$-ethylmaleimide and monoiodoacetate. $N$-Bromosuccinimide abolished the enzymic activity, and CMC protected the enzyme from inactivation by this tryptophan-specific oxidant. It is suggested that a tryptophan residue(s) is involved in the mechanism of action of the Bacillus cellulase and that the inhibition of enzymic activity by $\mathbf{H g}^{2+}$ is ascribable to interactions with the tryptophan residue(s) rather than with thiol group(s).
\end{abstract}

\section{Introduction}

Cellulolytic enzymes have been reported in several bacterial genera, namely Clostridium (Garcia-Martinetz et al., 1980; $\mathrm{Ng} \&$ Zeikus, 1981; Wu et al., 1988), Cellulomonas (Stoppok et al., 1982; Nakamura \& Kitamura, 1983), Ruminococcus (Gardner et al., 1987), Bacteroides (Saddler \& Khan, 1979) and Acetivibrio (Saddler et al., 1980). Members of the genus Bacillus also produce cellulases (e.g. Tewari \& Chahal, 1977; Horikoshi et al., 1984; Robson \& Chambliss, 1984; Dhillon et al., 1985; Au \& Chan, 1987). However, cellulases from Bacillus have received very limited attention, probably because most of these enzymes hydrolyse carboxymethylcellulose (CMC) but barely hydrolyse crystalline forms of cellulose and, furthermore, they have had no commercial applications until recently.

We have reported that the properties of alkaline carboxymethylcellulases (CMCase, endo-1,4- $\beta$-glucanase, EC 3.2.1.4) from some isolates of Bacillus conform

Abbreviations: CMC, carboxymethylcellulose; CMCase, carboxymethylcellulase: NBS, $N$-bromosuccinimide; NPC, 4-nitrophenyl- $\beta$-Dcellobioside; NPG, 4-nitrophenyl- $\beta$-D-glucopyranoside. to the essential requirements for enzymes that can be used as effective additives in laundry detergents (Kawai et al., 1988; Ito et al., 1989; Shikata et al., 1990). One of the isolates is currently used for the large-scale industrial production of an alkaline CMCase for this purpose (Ito $e t$ al., 1989). Therefore, cellulases from Bacillus have attracted our attention both because of our interest in their mechanisms of action (Okoshi et al., 1990; Yoshimatsu et al., 1990) and because of our interest in some genetic aspects of these enzymes (Ozaki et al., 1990). The genes for some alkaline cellulases have been sequenced (Horikoshi \& Fukumori, 1988; Ozaki et al., 1990), as have some genes for neutral cellulases from Bacillus (MacKay et al., 1986; Robson \& Chambliss, 1987; Nakamura et al., 1987). However, the nucleotide sequences of the genes for alkaline cellulases are too similar to those of the neutral enzymes to explain the difference in $\mathrm{pH}$ optima of these enzymes (Horikoshi \& Fukumori, 1988; Ozaki et al., 1990).

In order to clarify the mechanism of action of cellulases, with a special focus on differences in $\mathrm{pH}$ optima, we isolated a Bacillus strain, KSM-330, that produces a CMCase that is active over a very narrow 
range of acidic $\mathrm{pH}$ values, with the optimum $\mathrm{pH}$ being $5 \cdot 2$. The aim of this study was to purify and characterize the acid CMCase in the hope that the enzymic properties of this enzyme could later be applied to a genetic search for the amino acid sequence and tertiary structure that determine the $\mathrm{pH}$ optima for activity of cellulases from Bacillus.

\section{Methods}

Organism. The organism used was Bacillus sp. KSM-330. It was obtained from the stock culture collection of the Microbiology Laboratory of Tochigi Research Laboratories of Kao Corporation, Japan. This strain was originally isolated from a soil sample collected in Japan. Morphological and taxonomical characteristics of the isolated strain were examined according to the methods of Gordon et al. (1973) and Claus \& Berkeley (1986).

Bacillus sp. KSM-330 was propagated at $30{ }^{\circ} \mathrm{C}$ in a medium composed of $(\mathrm{w} / \mathrm{v}): 1 \%$ Polypepton (Daigo-Eiyo), $0.5 \%$ yeast extract (Difco), $\quad 0.1 \% \quad \mathrm{KH}_{2} \mathrm{PO}_{4}, \quad 0.25 \% \quad \mathrm{Na}_{2} \mathrm{HPO}_{4} .12 \mathrm{H}_{2} \mathrm{O}, \quad 0.02 \%$ $\mathrm{MgSO}_{4} \cdot 7 \mathrm{H}_{2} \mathrm{O}$ and $1 \%$ carbon source ( $\mathrm{pH} \mathrm{6.8)}$ ).

Preparation of crude enzyme. Bacillus sp. KSM-330 was propagated in the growth medium with $1.0 \%(\mathrm{w} / \mathrm{v})$ maltose at $30^{\circ} \mathrm{C}$ with shaking. After a $24 \mathrm{~h}$ incubation, cells were removed by centrifugation $(9800 \mathrm{~g}$, $10 \mathrm{~min})$ at $4{ }^{\circ} \mathrm{C}$. All further manipulations were also conducted at this temperature. The culture supernatant obtained $(0.6 \mathrm{l})$ was concentrated to a small volume by ultrafiltration on an H1 P3-20 hollow-fibre module ( $3 \mathrm{kDa}$ cutoff; Amicon). The concentrate $(70 \mathrm{ml})$ was dialysed four times over the course of $20 \mathrm{~h}$ against 40 vols each time of 10 mM-sodium phosphate buffer ( $\mathrm{pH} 7.2)$ and was then used as the crude enzyme preparation.

Purification of the enzyme. The crude enzyme preparation was applied immediately to a column of CM-Bio-Gel A $(3.2 \mathrm{~cm} \times 20 \mathrm{~cm}$; Bio-Rad) equilibrated with $10 \mathrm{~mm}$-phosphate buffer $(\mathrm{pH} \mathrm{7.2)}$. The column was first washed with $350 \mathrm{ml}$ of the equilibration buffer and then proteins were eluted with a 2 litre linear gradient of 0 to $0.3 \mathrm{M}$ $\mathrm{NaCl}$ in the equilibration buffer, at a flow rate of $35 \mathrm{ml} \mathrm{h}^{-1}$. Fractions of $5.0 \mathrm{ml}$ were collected from the start of the gradient. The elution pattern was monitored by measuring the absorbance at $280 \mathrm{~nm}\left(A_{280}\right)$ of each fraction, and then the CMCase activity in each fraction was measured. CMCase activity in some of these fractions was also checked by both protein and activity stains after nondenaturing PAGE. Two peaks of CMCase activity, a major peak A (tubes nos 284-306) and a minor peak B (tubes nos 271-280), were eluted and were separately pooled and used as the final preparations of purified enzymes. The material in the major peak $\mathrm{A}$ was designated Endo-K.

Electrophoresis. Polyacrylamide gel electrophoresis (PAGE) was performed on $7.5 \%(\mathrm{w} / \mathrm{v})$ polyacrylamide slab gels $(70 \mathrm{~mm} \times 80 \mathrm{~mm}$, $1 \mathrm{~mm}$ thickness) by the method of Reisfeld et al. (1962), at a constant current of $40 \mathrm{~mA}$, with $\beta$-alanine/acetic acid buffer $(\mathrm{pH} \mathrm{4.5)}$ as the running buffer. Sodium dodecyl sulphate (SDS)-PAGE was carried out on $12 \%(\mathrm{w} / \mathrm{v})$ polyacrylamide slab gels with $25 \mathrm{~mm}$-Tris $/ 192 \mathrm{~mm}$ glycine buffer $(\mathrm{pH} 8.3)$ that contained $0.1 \%(\mathrm{w} / \mathrm{v})$ SDS as the running buffer, after the enzyme preparations had been heated at $95{ }^{\circ} \mathrm{C}$ for $5 \mathrm{~min}$ in $62.5 \mathrm{~mm}$-Tris $/ \mathrm{HCl}$ buffer $(\mathrm{pH} 6.8)$ that contained $2.0 \%(\mathrm{w} / \mathrm{v})$ SDS, $10 \%(\mathrm{v} / \mathrm{v})$ glycerol and $5 \%(\mathrm{v} / \mathrm{v}) 2$-mercaptoethanol (Laemmli, 1970). Isoelectric focusing of Endo-K was performed by PAGE, as described by Wrigley (1971). The purified enzyme $(13 \mu \mathrm{g})$ was subjected to electrophoresis on a column $(0.5 \mathrm{~cm} \times 8.5 \mathrm{~cm})$ of $5 \%(\mathrm{w} / \mathrm{v})$ acrylamide gel that contained $13.3 \%(\mathrm{v} / \mathrm{v})$ glycerol and $1.9 \%(\mathrm{v} / \mathrm{v})$
Pharmalyte (pH range 3-10; Pharmacia), at a constant voltage of $300 \mathrm{~V}$ for $14 \mathrm{~h}$ at $10{ }^{\circ} \mathrm{C}$, with the cathode in the upper chamber $(20 \mathrm{~mm}$ $\left.\mathrm{H}_{3} \mathrm{PO}_{4}\right)$ and the anode in the lower $(0 \cdot 1 \mathrm{M}-\mathrm{NaOH})$. The isoelectric point was determined by cutting out zones of gel, eluting them and measuring the $\mathrm{pH}$ of the eluates.

Activity staining of CMCase in the slab gel was performed essentially by the methods of Béguin (1983) and Yoshimatsu et al. (1990). The slab gel after nondenaturing PAGE was laid on top of a

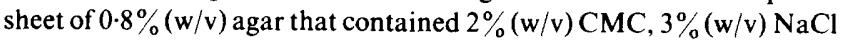
and $50 \mathrm{~mm}$-sodium citrate/citric acid buffer (pH 5.2) and was left for $2 \mathrm{~h}$ at $30^{\circ} \mathrm{C}$. The $\mathrm{CMC}$-agar sheet was washed in $0.5 \mathrm{~m}$-glycine $/ \mathrm{NaOH}$ buffer ( $\mathrm{pH} \mathrm{9.5)} \mathrm{for} 15 \mathrm{~min}$, stained by flooding with $0.1 \%(\mathrm{w} / \mathrm{v})$ Congo red for $15 \mathrm{~min}$ and then destained in $1.0 \mathrm{M}-\mathrm{NaCl}$ for $15 \mathrm{~min}$, at room temperature. The bands of protein that were associated with $\mathrm{CMCase}$ activity were seen as clear zones on the CMC-agar sheet, which formed a dark-red background. Proteins were located by the silver-staining method (Oakley et al., 1980).

Determination of molecular mass. Molecular mass was established both by SDS-PAGE and by gel filtration on a column of Bio-Gel P100medium. The Bio-Gel column $(1.6 \mathrm{~cm} \times 92 \mathrm{~cm})$ was equilibrated with $10 \mathrm{~mm}$-phosphate buffer ( $\mathrm{pH} 7 \cdot 2)$ supplemented with $0 \cdot 1 \mathrm{M}-\mathrm{NaCl}$ and calibrated by elution of molecular mass markers (Pharmacia) that included bovine serum albumin $(67 \mathrm{kDa})$, ovalbumin $(43 \mathrm{kDa})$, chymotrypsinogen A $(25 \mathrm{kDa})$ and RNAase A $(13.7 \mathrm{kDa})$. The phosphate buffer was used as elution buffer and the eluate was collected in $1 \mathrm{ml}$ fractions at a flow rate of $5.8 \mathrm{ml} \mathrm{h}^{-1}$. For the determination of molecular mass by SDS-PAGE, molecular mass markers for SDSPAGE (Bio-Rad) were used: hen egg white ovalbumin $(42.7 \mathrm{kDa})$, bovine carbonic anhydrase $(31 \mathrm{kDa})$, soybean trypsin inhibitor $(21.5 \mathrm{kDa})$ and hen egg white lysozyme (14.4 kDa).

Enzyme assays. Assays for cellulolytic activity of Endo-K against CMC (degree of substitution 0.68, Sanyo Kokusaku Pulp), Avicel (Merck), phosphoric acid-swollen cellulose, lichenan (from Cetraria islandica, Sigma), laminarin (from Laminaria digitata, Sigma) and curdlan (from Alcaligenes faecalis var. mixogenes, Wako Pure Chemical) were performed essentially according to published procedures (Kawai et al., 1988: Ito et al., 1989). The acid-swollen cellulose was prepared from cellulose powder (Toyo Roshi) by the method of Tomita et al. (1974). For the CMCase assay, $0.1 \mathrm{ml}$ of enzyme solution and $0.9 \mathrm{ml}$ of $1.1 \%(\mathrm{w} / \mathrm{v}) \mathrm{CMC}$ in $0.11 \mathrm{M}$-citrate buffer $(\mathrm{pH} \mathrm{5.2)}$ were mixed and incubated for $20 \mathrm{~min}$ at $40^{\circ} \mathrm{C}$. The reducing sugar formed was quantified as glucose by the dinitrosalicylic acid procedure (Miller $e t$ al., 1960). Depolymerization (liquefaction) of CMC was measured viscometrically at $40^{\circ} \mathrm{C}$ in the above reaction using an Ubbelohde viscometer, and was also detected by the liquefaction of the CMC-agar sheet used for activity staining. Lichenan-hydrolysing activity was measured in the same way as the assay for CMCase described above.

For the assays of hydrolytic activities against the other cellulosic substrates, each reaction mixture contained $0.1 \mathrm{ml}$ of a suitably diluted solution of Endo-K, $0.9 \mathrm{ml}$ of $0.11 \mathrm{M}$-citrate buffer $(\mathrm{pH} 5 \cdot 2)$ and $50 \mathrm{mg}$ substrate. This mixture was incubated for $2-12 \mathrm{~h}$ at $40^{\circ} \mathrm{C}$ with stirring. After incubation, solids were removed by centrifugation at $20^{\circ} \mathrm{C}$ $(8000 \mathrm{~g}, 10 \mathrm{~min})$ and the enzymic activity of the supernatant was measured as described by Miller et al. (1960).

Assays for hydrolytic activities against 4-nitrophenyl- $\beta$-D-glucopyranoside, (NPG, Sigma) and 4-nitrophenyl- $\beta$-D-cellobioside (NPC, Sigma) were done with $8 \mathrm{~mm}$-substrate and a sample of Endo-K in $1.0 \mathrm{ml}$ of $0.1 \mathrm{M}$-citrate buffer ( $\mathrm{pH} \mathrm{5.2)}$ ); reactions were incubated for an appropriate length of time (up to $4 \mathrm{~h}$ ) at $40^{\circ} \mathrm{C}$. Each reaction was stopped by the addition of $0.4 \mathrm{ml} 1 \mathrm{M}-\mathrm{Na}_{2} \mathrm{CO}_{3}$ and the 4-nitrophenol liberated was quantified at $410 \mathrm{~nm}$, using an $\varepsilon$ value of $120001 \mathrm{~mol}^{-1}$ $\mathrm{cm}^{-1}$. For the assay of cellobiase, $0.1 \mathrm{ml}$ enzyme solution was mixed with $0.9 \mathrm{ml} 1.1 \%(\mathrm{w} / \mathrm{v})$ cellobiose in $0.11 \mathrm{M}$-citrate buffer ( $\mathrm{pH} 5.2)$. The mixture was incubated for $10 \mathrm{~min}$ at $40{ }^{\circ} \mathrm{C}$, and the amount of glucose 
formed was determined by use of glucose oxidase/peroxidase (Glucose C-Test; Wako Pure Chemical).

Protein was determined by the procedure of Bradford (1976) with bovine plasma albumin as protein standard and a protein assay kit (Bio-Rad). One unit (U) of enzymic activity was defined as the amount of protein that produces $1.0 \mu \mathrm{mol}$ of product $\mathrm{min}^{-1}$ under the standard assay conditions.

Chromatographic analysis of the products of hydrolysis of cellooligosaccharides. Samples $(50 \mathrm{mg})$ of cello-oligosaccharide, namely cellobiose through cellohexaose (Seikagaku Kogyo), were dissolved in $1.0 \mathrm{ml} 0 \cdot 1 \mathrm{M}$-citrate buffer $(\mathrm{pH} 5 \cdot 2)$. A portion $(0.1 \mathrm{ml})$ of the reaction mixture was incubated with a sample of Endo- $\mathrm{K}(5.6 \mathrm{mU})$ at $40^{\circ} \mathrm{C}$ for $16 \mathrm{~h}$ and an aliquot $(10 \mu \mathrm{l})$ of the hydrolysate was subjected to thin-layer chromatography on a silica gel 60 plate $(20 \mathrm{~cm} \times 20 \mathrm{~cm}$; Merck $)$, in a solvent system of $n$-butanol/pyridine/water $(6: 4: 3$, by vol.). After one to four ascents of solvent at room temperature, the chromatogram was developed by heating the plate at $80^{\circ} \mathrm{C}$ for $15 \mathrm{~min}$ after spraying with aniline/diphenylamine/phosphoric acid solution (Bailey \& Bourne, 1960).

Amino-terminal sequence of Endo- $K$. The purified enzyme $(37.8 \mu \mathrm{g}$, equivalent to approx. $0.9 \mathrm{nmol}$ ) was concentrated and desalted by centrifugation in a centrifuge tube concentrator (Centricon 10, Amicon). The $\mathrm{N}$-terminal amino acid residues of the enzyme in this preparation were determined by automated Edman sequencing with a 477A sequenator (Applied Biosystems; Hunkapiller et al., 1983). For the fractionation and detection of phenylthiohydantoin (PTH) derivatives of amino acids, a 120A PTH-amino acid analyser (Applied Biosystems) was used.

Reaction of Endo- $\mathrm{K}$ with $\mathrm{N}$-bromosuccinimide (NBS). Titration of Endo-K with NBS (Wako Pure Chemical) was done essentially by the method of Spande \& Witkop (1967). To $60 \mu$ l deionized water, $10 \mu 10.5$ M-acetate buffer ( $\mathrm{pH} \mathrm{4.0)}, 20 \mu$ l enzyme solution $(26 \mu \mathrm{g}$ protein, $1.35 \mathrm{U}$ ) and, finally, $10 \mu \mathrm{J} 10 \mathrm{~mm}$-acetate buffer ( $\mathrm{pH} 4.0$ ) containing NBS at a suitable concentration were added. After $5 \mathrm{~min}$ incubation at $30^{\circ} \mathrm{C}$, a $10 \mu \mathrm{l}$ sample was withdrawn and quenched by the addition of $0.59 \mathrm{ml}$ acetate buffer containing $15 \mathrm{~mm}$-tryptophan; the residual CMCase activity in this fraction was then determined. The remaining mixture $(90 \mu \mathrm{l})$ was used to measure the change in $A_{280}$ of the NBS-treated enzyme in a Beckman DU-65 spectrophotometer with a 5-karat microcell. Appropriate controls with $50 \mathrm{~mm}$-acetate buffer ( $\mathrm{pH} \mathrm{4.0)}$ containing NBS were included for measurements of background absorbance. The number of tryptophan residues oxidized $(N)$ was calculated from the following equation: $N=\left(1.31 \times\right.$ change in $\left.A_{280}\right)$ $(5500 \times \text { molarity of enzyme })^{-1}$, where the molecular mass adopted was $42 \mathrm{kDa}$ in the case of Endo- $\mathrm{K}$ and $55001 \mathrm{~mol}^{-1} \mathrm{~cm}^{-1}$ is the molar absorption coefficient of tryptophan at $280 \mathrm{~nm}$.

\section{Results}

\section{Taxonomic characterization of the isolated strain}

The isolate, KSM-330, was an obligately aerobic, sporeforming (cylindrical, subterminal to paracentral, without a swollen sporangium), Gram-positive, motile and rodshaped bacterium $(0.9-1.0 \mu \mathrm{m} \times 2.5-3.0 \mu \mathrm{m})$. The organism was positive for formation of acetoin (V-P test), reduction of nitrate, decomposition of casein and growth in $7 \%(\mathrm{w} / \mathrm{v}) \mathrm{NaCl}$. It seemed likely that this isolate was a relative of $B$. subtilis, although it was negative for hydrolysis of starch and production of acid from arabinose, xylose and mannitol.

\section{Purification}

When Bacillus sp. KSM-330 was grown on the medium that contained $1 \%(\mathrm{w} / \mathrm{v}) \mathrm{CMC}, \mathrm{CMCase}$ activity $\left(1.22 \mathrm{U} \mathrm{ml}^{-1}\right)$ was maximal after $24 \mathrm{~h}$, corresponding to the late-exponential or stationary phase of growth. In order to simplify the purification of the CMCase, the production of the enzyme during growth in the presence of metabolizable carbohydrates other than CMC was examined. When cells were grown on $1 \%(\mathrm{w} / \mathrm{v})$ maltose, glucose and fructose separately, the CMCase activity after $24 \mathrm{~h}$ was $1.86,1.23$ and $1.82 \mathrm{U} \mathrm{ml}^{-1}$, respectively, and the activity in cells grown in control medium (without carbohydrate) was $1.04 \mathrm{U} \mathrm{ml}^{-1}$. Therefore, the medium supplemented with maltose was chosen for the production of CMCase by Bacillus sp. KSM-330.

On chromatography of the crude enzyme on a $\mathrm{CM}$ Bio-Gel A column, two peaks of CMCase activity, a major peak A (Endo-K ; tubes nos 284-306) and a minor peak B (tubes nos 271-280), were detected, with an activity ratio of approximately $15: 1$. The degree of purification and total recovery are summarized in Table 1. The specific activities were 51.6 and $58.3 \mathrm{U}(\mathrm{mg}$ protein $)^{-1}$ for peak A and peak B, respectively. A very high overall yield of CMCase activity was achieved $(71.4 \%$ of the initial activity).

\section{Homogeneity, molecular mass and $N$-terminal amino acid sequence}

The two purified preparations of enzyme were tested for purity by nondenaturing PAGE and SDS-PAGE. Both nondenaturing PAGE and SDS-PAGE gave single bands of protein when proteins were visualized by silver staining. The enzyme in peak A migrated slightly faster than that in peak $B$ during nondenaturing PAGE, but both enzymes migrated at almost the same rate during SDS-PAGE. Each band of protein, detected by staining after nondenaturing PAGE, coincided fairly well with the band visualized by activity staining with Congo red.

The molecular masses of the two enzymes were estimated to be $39 \mathrm{kDa}$ by gel chromatography on a column of Bio-Gel P100-medium. SDS-PAGE also gave the same subunit molecular mass of $42 \mathrm{kDa}$ for both enzymes. These results indicate that both enzymes have a monomeric structure. Both enzymes showed almost the same profiles in terms of $\mathrm{pH}$ for activity, stability to changes in $\mathrm{pH}$, temperature for activity and stability to heating (data not shown). Endo-K, the material in the major peak A, was chosen for further study.

The isoelectric point of Endo-K was higher than $\mathrm{pH}$ 10. The N-terminal amino acid sequence of Endo-K, determined on a gas-phase protein/peptide sequencer, was Val-Ala-Lys-Glu-Met-Lys-Pro-Phe-Pro-Gln-GlnVal-Asn-Tyr-Ser-Gly-Ile-Leu-Lys-Pro. 
Table 1. Purification of CMCase activities from Bacillus sp. KSM-330

\begin{tabular}{lccccc}
\hline \hline $\begin{array}{c}\text { Purification } \\
\text { step }\end{array}$ & $\begin{array}{c}\text { Total } \\
\text { protein } \\
(\mathrm{mg})\end{array}$ & $\begin{array}{c}\text { Total } \\
\text { activity } \\
(\mathrm{U})\end{array}$ & $\begin{array}{c}\text { Specific } \\
\text { activity } \\
\left(\mathrm{U} \mathrm{mg}^{-1}\right)\end{array}$ & $\begin{array}{c}\text { Yield } \\
(\%)\end{array}$ & $\begin{array}{c}\text { Purification } \\
\text { (-fold) }\end{array}$ \\
\hline $\begin{array}{l}\text { Crude enzyme } \\
\text { CM-Bio-Gel A }\end{array}$ & 64 & 1036 & 16.2 & 100 & 1.0 \\
Peak A & 13.4 & 692 & 51.6 & 66.8 & 3.2 \\
Peak B & 0.82 & 47.8 & 58.3 & 4.6 & 3.6 \\
\hline
\end{tabular}

Table 2. Substrate specificity of Endo-K

Assays for CMC- and lichenan-hydrolysing activities were performed at $40^{\circ} \mathrm{C}$ in $0.1 \mathrm{M}$-citrate buffer (pH 5.2) with $0.58 \mu \mathrm{g}$ enzyme under the standard reaction conditions. For the assays of the other substrates, $11.5 \mu \mathrm{g}$ enzyme was used in each experiment. The numbers in parentheses show the relative activities, the activity against CMC being taken as $100 \%$.

\begin{tabular}{lc}
\hline \hline \multicolumn{1}{c}{ Substrate $(1 \%)$} & Endo-K activity $\left(\mathrm{U} \mathrm{mg}^{-1}\right)$ \\
\hline $\mathrm{CMC}$ & $51 \cdot 6(100)$ \\
Avicel & $0 \cdot 005(0 \cdot 0097)$ \\
$\mathrm{H}_{3} \mathrm{PO}_{4}$-swollen cellulose & $0 \cdot 139(0 \cdot 268)$ \\
Lichenan & $59 \cdot 9(115 \cdot 6)$ \\
Curdlan & 0 \\
Laminarin & 0 \\
NPC $^{*}$ & 0 \\
NPG $^{*}$ & 0 \\
\hline \hline
\end{tabular}

* Assays were done with $8 \mu \mathrm{mol}$ substrate and $5.8 \mu \mathrm{g}$ enzyme.

\section{Substrate specificity of Endo-K}

The purified preparation of Endo-K was examined for its ability to hydrolyse various carbohydrates and arylglycosides at $40^{\circ} \mathrm{C}$ and at $\mathrm{pH} 5.2$ in $0.1 \mathrm{M}$-citrate buffer (Table 2). Of the carbohydrate substrates tested, CMC $(\beta$-1,4-linkage) and lichenan $(\beta$-1,3;1,4-linkage) were efficiently hydrolysed by Endo-K at almost the same rate. The enzyme rapidly decreased the viscosity of a solution of CMC (data not shown). Avicel, phosphoricacid-swollen cellulose, cellobiose, curdlan $(\beta-1,3-$ linkage), laminarin ( $\beta-1,3 ; 1,6$-linkage), NPG and NPC were practically unhydrolysable by Endo-K.

Cello-oligosaccharides were hydrolysed by Endo- $\mathrm{K}$ to an equilibrium end-point ( $16 \mathrm{~h}$ of incubation) at $40{ }^{\circ} \mathrm{C}$ and $\mathrm{pH} 5.2$ in $0.1 \mathrm{M}$-citrate buffer. The enzyme acted on cellopentaose to generate cellobiose and cellotetraose, and on cellohexaose to generate cellobiose, cellotriose and cellotetraose, as the major products of hydrolysis. With cellotetraose as substrate, a large amount remained intact, with the products of hydrolysis being glucose, cellobiose and cellotriose. The enzyme was not active on cellobiose or cellotriose.

\section{Effect of $p H$ on the activity and stability of Endo-K}

The effect of $\mathrm{pH}$ on the activity of Endo-K was determined at $40{ }^{\circ} \mathrm{C}$ in various buffers ranging from $\mathrm{pH} 2.1$ to $\mathrm{pH} 11.9$, as shown in Fig. 1(a). Maximal activity toward CMC was observed at $\mathrm{pH} 5.2$ in 0.1 M-citrate buffer. The enzyme was active over a very narrow range of $\mathrm{pH}$ values, between 4.2 and 6.9 , with less than $5 \%$ of the maximum activity detectable above and below these $\mathrm{pH}$ values. A $\mathrm{pH}$-activity curve with a similar profile was obtained with lichenan as substrate. To determine the short-term stability of the enzyme activity with changes in $\mathrm{pH}$, Endo-K was preincubated at $40{ }^{\circ} \mathrm{C}$ for $10 \mathrm{~min}$ in various buffers ranging from $\mathrm{pH} 2.5$ to $\mathrm{pH} 10.7$ and then assayed at $\mathrm{pH} 5.2$ and $40^{\circ} \mathrm{C}$. The enzyme was stable to incubation over a broad range between $\mathrm{pH} 3.2$ and $\mathrm{pH} 9.5$ (Fig. 1 b). The activity was lost when the enzyme was incubated at $\mathrm{pH} 2.5$ or $\mathrm{pH} 10.7$ under these conditions.

\section{Effect of temperature on the activity and stability of Endo-K}

The dependence on temperature of Endo- $\mathrm{K}$ activity toward $\mathrm{CMC}$ was determined by measuring the activity at various temperatures in $0 \cdot 1 \mathrm{M}$-citrate buffer ( $\mathrm{pH} 5 \cdot 2$ ). Maximal activity with $\mathrm{CMC}$ as substrate was detected at around $45^{\circ} \mathrm{C}$. At $10^{\circ} \mathrm{C}$ more than $25 \%$ of the maximum activity was detected, whereas at temperatures above $60{ }^{\circ} \mathrm{C}$ the enzyme was inactive. The stability to heating of Endo-K was examined after the enzyme had been heated at various temperatures for $10 \mathrm{~min}$ in $0.1 \mathrm{M}$-citrate buffer (pH 5.2). The enzyme was quite stable in the absence of additives up to $50{ }^{\circ} \mathrm{C}$. Above this temperature, the stability of the enzyme decreased rapidly, with less than $5 \%$ of the original activity remaining after $10 \mathrm{~min}$ at $60^{\circ} \mathrm{C}$.

\section{Effects of chemical reagents}

Endo-K and each chemical $(1 \mathrm{mM})$ were mixed and incubated at $30^{\circ} \mathrm{C}$ for $30 \mathrm{~min}$ in $1.0 \mathrm{ml}$ of $50 \mathrm{mM}$-MOPS buffer and an aliquot $(0.1 \mathrm{ml})$ was used for the assay of 


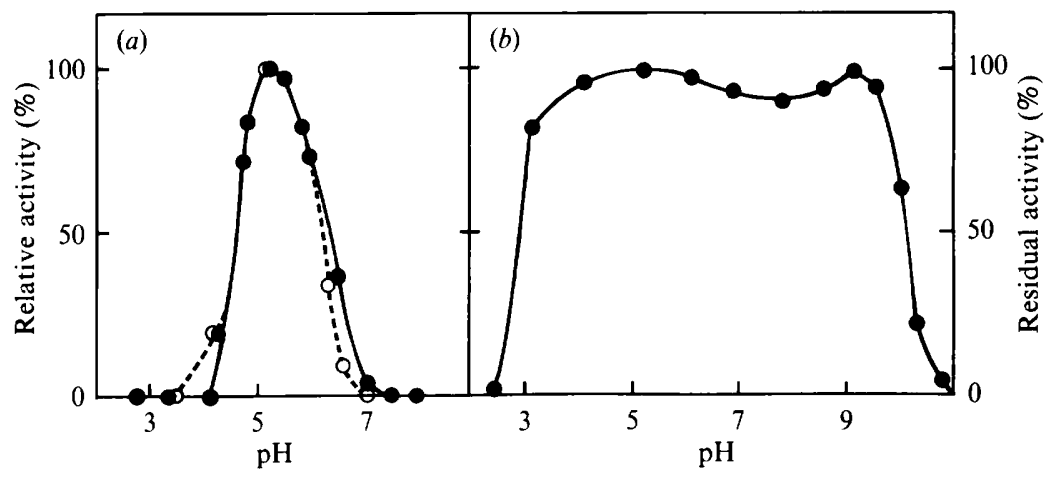

Fig. 1. Effect of $\mathrm{pH}$ on the activity and stability of Endo-K. Sodium citrate/ $\mathrm{HCl}$ buffer ( $\mathrm{pH} \mathrm{2} \cdot 5-4 \cdot 2$ ), sodium citrate/citric acid buffer ( $\mathrm{pH} 3 \cdot 2-6 \cdot 3$ ), sodium phosphate buffer (pH 6.1-7.5), Tris/HCl buffer (pH 7.0-8.8), glycine/ $\mathrm{NaOH}$ buffer ( $\mathrm{pH} 8.7-$ $10 \cdot 1)$ and $\mathrm{Na}_{2} \mathrm{HPO}_{4} / \mathrm{NaOH}$ buffer (pH 9.3-10.7) were used. (a) pH-activity curve for Endo-K. Assays were done at $40^{\circ} \mathrm{C}$ in the indicated buffers at $0.1 \mathrm{M}$, at various $\mathrm{pH}$ values, with $0.43 \mu \mathrm{g}$ enzyme, using $\mathrm{CMC}(\odot)$ and lichenan $(O)$ as substrates. Each enzyme activity at pH 5.2 in $0.1 \mathrm{M}$ citrate buffer was taken as $100 \%$. (b) $\mathrm{pH}$-stability curve for the enzyme. Enzyme $(243 \mathrm{mU})$ was preincubated at the indicated $\mathrm{pH}$ in $1.0 \mathrm{ml}$ of $50 \mathrm{~mm}$-buffer for $10 \mathrm{~min}$ at $40^{\circ} \mathrm{C}$. Aliquots of $0.1 \mathrm{ml}$ were withdrawn and the residual CMCase activity was measured at $40^{\circ} \mathrm{C}$ and $\mathrm{pH} 5.2$ in $0.1 \mathrm{M}$ citrate buffer with $0.47 \mu \mathrm{g}$ enzyme. Control activity $(100 \%)$ was $24.3 \mathrm{mU}$ under standard conditions of the assay. the residual CMCase activity in $0.1 \mathrm{M}$-citrate buffer (pH 5.2). The enzyme was not significantly affected by the following cations: $\mathrm{Ca}^{2+}, \mathrm{Mg}^{2+}, \mathrm{Co}^{2+}, \mathrm{Mn}^{2+}, \mathrm{Ni}^{2+}$, $\mathrm{Cd}^{2+}, \mathrm{Zn}^{2+}, \mathrm{Pb}^{2+}, \mathrm{Cu}^{2+}, \mathrm{Fe}^{2+}, \mathrm{Fe}^{3+}, \mathrm{Na}^{+}$and $\mathrm{K}^{+}$. The notable exception was $\mathrm{Hg}^{2+}(40 \%$ inhibition). Reagents specific for thiol groups, such as $N$-ethylmaleimide, monoiodoacetate and 4-chloromercuribenzoate (1 mM) had little if any effect on the enzyme. The chelating reagents, EDTA and EGTA, each added at $1 \mathrm{~mm}$, were without effect, suggesting that these compounds did not chelate a possible divalent cation(s) required for the activity of Endo-K. Phenylmethylsulphonyl fluoride and diisopropylfluorophosphate, strong inhibitors of serine enzymes, also had almost no effect. However, NBS, at a concentration of less than $0.1 \mathrm{~mm}$, abolished the activity of Endo-K completely at pH 4.0 in $50 \mathrm{~mm}$-acetate buffer.

\section{Interaction of $N$-bromosuccinimide with Endo- $K$}

Strong inhibition of Endo-K activity by NBS suggests a crucial involvement of tryptophan residue(s) at the active site of the enzyme. As shown in Fig. 2(a), the peak of absorbance of Endo-K at $280 \mathrm{~nm}$ decreased in the presence of increasing amounts of NBS. This decrease was accompanied by an increase in the $A_{250}$ of the enzyme. This result suggests that oxidation of tryptophan occurred in the enzyme molecule (Spande \& Witkop, 1967). The effect of NBS on the enzyme activity and the number of tryptophan residues oxidized are shown in Fig. 2(b), as a function of the amount of NBS added. The inactivation of enzyme activity by NBS at each concentration was complete within $5 \mathrm{~min}$ and further inactivation did not occur after an additional $10-20 \mathrm{~min}$ of incubation. There was a correlation between the loss of activity and the number of tryptophan residues oxidized. The molar concentration of NBS required for complete inactivation of one mole of Endo-K activity was calculated to be approximately 4, and the measured titre of tryptophan residues in the enzyme finally reached 11.4 (data not shown). The complete inactivation of Endo-K by the addition of a low molar excess of NBS indicates that one of the tryptophan residues is essential for activity. Fig. 2(c) shows that the presence of CMC efficiently protected the enzyme from inactivation by NBS added up to a concentration of $12 \mu \mathrm{M}$. This result provides further evidence for the crucial involvement of a tryptophan residue in the mechanism of action of Endo-K.

\section{Discussion}

Some species of Bacillus, such as $B$. subtilis, B. firmus, $B$. pumilus, $B$. cereus, $B$. polymyxa and $B$. brevis are known to produce endo-1,4- $\beta$-glucanase (CMCase) activities (Knösel, 1971; Fogarty \& Griffin, 1973; Fogarty et al., 1974; Thayer, 1978). In the present study, we also isolated an obligately aerobic strain of Bacillus, KSM330, which produces an acid CMCase. However, very few attempts have been made to purify cellulases from Bacillus to homogeneity, possibly because of the multiple forms of the enzymes and/or the complexity of the cellulase system(s), or because of formation of fragmented enzymes by proteolytic events during growth of the organisms or purification of the enzymes. Ito and his colleagues have isolated a number of strains of Bacillus that produce alkaline CMCases suitable for use as detergent additives (Kawai et al., 1988; Ito et al., 1989; 

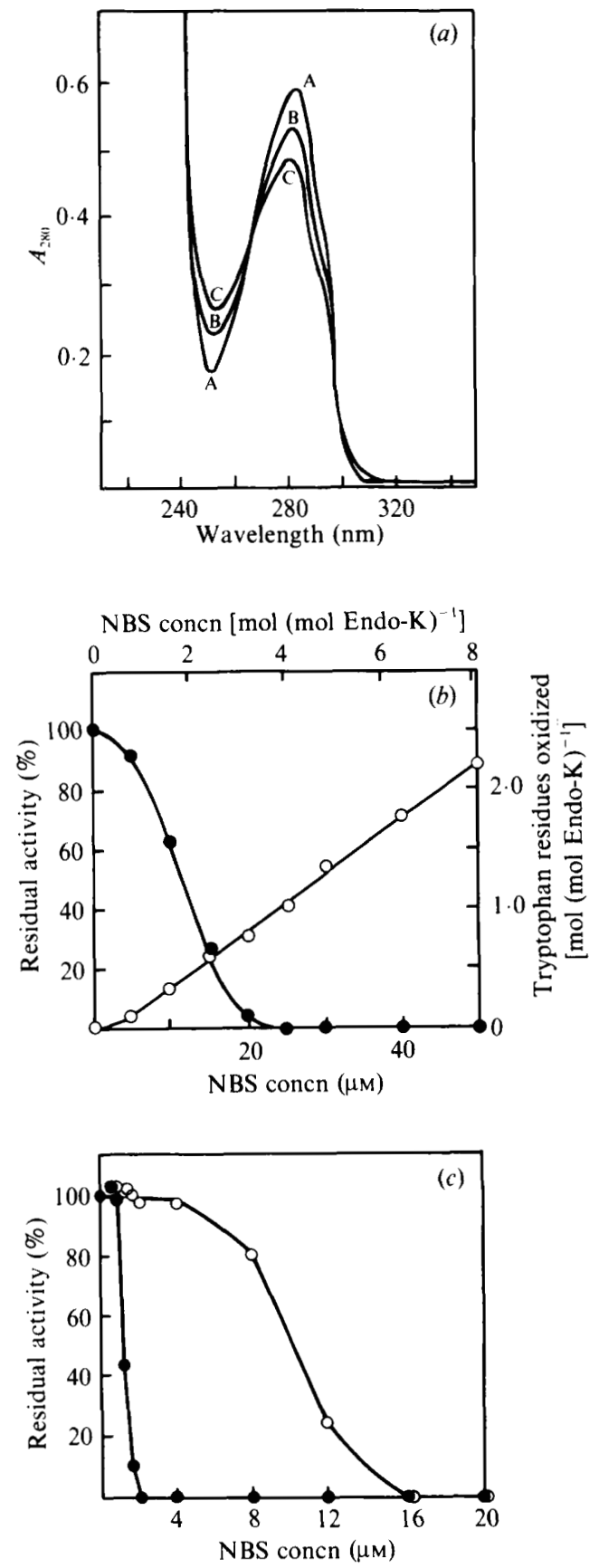

Fig. 2. Effect of NBS on Endo-K activity. Experimental details are described both in the Methods and elsewhere in the text. (a) Change in ultraviolet absorption of Endo-K. Absorption curves: A, not treated (without NBS); B, treated with $50 \mu \mathrm{M}-\mathrm{NBS}$; C, treated with $100 \mu \mathrm{M}-$ NBS. (b) Titration of Endo-K with NBS. $O$, Number of tryptophan residues, estimated by the method of Spande \& Witkop (1967); $\bullet$, residual activity. (c) Protection of Endo-K by CMC from inactivation by NBS in $50 \mathrm{~mm}$-acetate buffer ( $\mathrm{pH} 4.0)$. Endo-K $(5.9 \mu \mathrm{g}$ protein, corresponding to $0.14 \mathrm{nmol}$ of enzyme) and $0.1 \%(\mathrm{w} / \mathrm{v}) \mathrm{CMC}$ were preincubated for $20 \mathrm{~min}$ in $50 \mathrm{~mm}$-acetate buffer $(\mathrm{pH} \mathrm{4.0)}$ before the addition of NBS at the concentrations indicated. Then the residual enzyme activity was measured. Control activities; $O$, residual activities in the presence of $1.0 \%(\mathrm{w} / \mathrm{v}) \mathrm{CMC}$.
Shikata et al., 1990), and some of these enzymes have been purified to homogeneity with high yield and characterized (Okoshi et al., 1990; Yoshimatsu et al., 1990). An alkaline CMCase from the alkalophilic Bacillus sp. no. 1139 was purified and characterized to a limited extent by Fukumori et al. (1985), and a neutral CMCase from B. subtilis AU-1 was purified to homogeneity by Au \& Chan (1987).

In this study, we purified an acid CMCase, Endo-K, from Bacillus sp. KSM-330. In order to purify this enzyme with high yield, we used chromatography on CM-Bio-Gel A, instead of chromatography on CMcellulose or dialysis with cellulose membranes. In addition, cultures were harvested in the late-exponential phase of growth to avoid the formation of fragmented enzymes by proteolytic events at the $\mathrm{N}$ - or $\mathrm{C}$-terminus of Endo-K. The $\mathrm{pH}$-activity curve of the purified enzyme obtained in this way shows a very narrow range of $\mathrm{pH}$ values at which the enzyme is active, namely, $4 \cdot 2-6 \cdot 9$, the optimum $\mathrm{pH}$ being around $5 \cdot 2$. Such an unusually narrow range of $\mathrm{pH}$ values for CMCase activity has not been reported for other bacterial stains. Endo- and exo-1,4- $\beta$ glucanases from a fungus, Trichoderma harzianum, also have relatively narrow ranges of $\mathrm{pH}$ for activity, but the $\mathrm{pH}$-stability curves of these enzmes are very narrow compared with that of Endo-K (Sidhu et al., 1986). Endo$\mathrm{K}$ hydrolyses $\mathrm{CMC}$ and lichenan but displays only very low activity with Avicel and acid-swollen cellulose as substrates. The presence of a $\beta$-1,4-bond appears to be required for enzyme activity, since curdlan, a predominantly $\beta$-1,3-linked glucan, and laminarin, a predominantly $\beta$-1,6-linked glucan, were not degraded. Hence, it would probably be more appropriate to refer to Endo-K as an endo-1,4- $\beta$-glucanase rather than as a cellulase. The $\mathrm{N}$-terminal amino acid sequence of the enzyme was determined, and the first 20 amino acids of Endo-K match the sequence of amino acids 56 to 75 (numbered starting at the $\mathrm{N}$-terminal methionine) deduced from the open reading frame of the cloned gene for the enzyme (K. Ozaki \& S. Ito, unpublished observations).

Endo-K activity from Bacillus sp. KSM-330 was completely abolished by NBS. This result provides evidence for the crucial involvement of a tryptophan residue(s) in the active site of this enzyme. Our results provide the first evidence, to our knowledge, that a tryptophan residue(s) is precisely involved in the action of bacterial cellulase, although a tryptophan residue(s) has been suggested as essential for the action of fungal cellulases (Pettersson, 1968; Hurst et al., 1977; Clarke, 1987). The overall absence of inhibition of Endo-K activity by commonly used thiol reagents suggests that the inhibition by $\mathrm{Hg}^{2+}$ is not related to interactions of this heavy metal ion with cysteine residues in the enzyme molecule, and that Endo- $\mathrm{K}$ does not contain any thiol 
groups that are necessary for enzyme activity. Thus, sensitivity toward $\mathrm{Hg}^{2+}$ may be the result of the interaction with a tryptophan residue(s) at the active site of the Endo-K molecule, as suggested by Eriksson \& Pettersson (1968) and Hurst et al. (1977). In fact, the genetic analysis of the gene for Endo-K cloned from Bacillus sp. KSM-330 shows that the enzyme is devoid of cysteine residues (K. Ozaki \& S. Ito, unpublished data). The insensity toward monoiodoacetate also suggests a noncritical role for imidazole, methionine or amino groups (Hurst et al., 1977). The slight stimulation (about $20 \%$ ) by dithiothreitol and 2-mercaptoethanol, however, complicates the explanation of the contradictory results with $\mathrm{Hg}^{2+}$ and the thiol reagents tested. A similar stimulatory effect by 2-mercaptoethanol has been observed with an alkaline endo-1,4- $\beta$-glucanase from Bacillus sp. KSM-635, which is devoid of cysteine residues at the active site (Ozaki et al., 1990; Yoshimatsu et al., 1990).

In order to investigate further the unique $\mathrm{pH}$-activity pattern of Endo-K at the molecular level and the mechanisms of action of this enzyme, we have cloned the gene for Endo-K in Escherichia coli. The deduced amino acid sequence of Endo-K is being compared with those of both neutral and alkaline CMCases of microbial origin, with a specific focus on differences in $\mathrm{pH}$ optima for activity of these enzymes.

\section{References}

AU, K.-S. Chan, K.-Y. (1987). Purification and properties of the endo1,4- $\beta$-glucanase from Bacillus subtilis. Journal of General Microbiology 133, 2155-2162.

Bailey, R. W. \& Bourne, E. J. (1960). Colour reactions given by sugars and diphenylamine-aniline spray reagents on paper chromatograms. Journal of Chromatography 4, 206-213.

BÉGUIN, P. (1983). Detection of cellulase activity in polyacrylamide gels using Congo red-stained agar replicas. Analytical Biochemistry 131, 333-336.

BRADFORD, M. M. (1976). A rapid and sensitive method for the quantitation of microgram quantities of protein utilizing the principle of protein-dye binding. Analytical Biochemistry 72, 248-254.

ClaRKE, A. J. (1987). Essential tryptophan residues in the function of cellulase from Schizophyllum commune. Biochimica et Biophysica Acta 912, 424-431.

Claus, D. \& Berkeley, R. C. W. (1986). Genus Bacillus. In Bergey's Manual of Systematic Bacteriology, vol. 2, pp. 1105-1139. Edited by P. H. A. Sneath, N. S. Mair, M. E. Sharpe \& J. G. Holt, Baltimore: Williams \& Wilkins.

Dhillon, N., Chhibber, S., Saxena, M., Pajni, S. \& Vadehra, D. V. (1985). A constitutive endoglucanase (CMCase) from Bacillus licheniformis-1. Biotechnology Letters 7, 695-697.

Eriksson, K.-E. \& Pettersson, G. (1968). Studies on cellulolytic enzymes. V. Some structural properties of the cellulase from Penicillium notatum. Archives of Biochemistry and Biophysics 124, 160-166.
Fogarty, W. M. \& Griffin, P. J. (1973). Some preliminary observations on the production and properties of a cellulolytic enzyme elaborated by Bacillus polymyxa. Biochemical Society Transactions 1, 1297-1298.

Fogarty, W. M., Griffin, P. J. \& JoYce, A. M. (1974). Enzymes of Bacillus species-Part-1. Process Biochemistry July/August, 11-24.

FUkUMORI, F., KuDO, T. \& HoRIKoshI, K. (1985). Purification and properties of a cellulase from alkalophilic Bacillus sp. no. 1139. Journal of General Microbiology 131. 3339-3345.

Garcia-Martinetz, D. V., Shinmyo, A., Madia, A. \& Demain, A. L. (1980). Studies on cellulase production by Clostridium thermocellum. European Journal of Applied Microbiology and Biotechnology 9, 189-197.

GaRdNer, R. M., Doerner, K. C. \& White, B. A. (1987). Purification and characterization of an exo- $\beta$-1,4-glucanase from Ruminococcus flavefaciens FD-1. Journal of Bacteriology 169, 4581-4588.

Gordon, R. E., Haynes, W. C. \& PANG, C. H. (1973). The Genus Bacillus, Washington, DC: United States Department of Agriculture.

HORIKOSHI, K. \& FUKUMORI, F. (1988). Modification and expression of alkaline cellulase genes of alkalophilic Bacillus strains. In Biochemistry and Genetics of Cellulose Degradation, pp. 203-217. Edited by J.-P. Aubert, P. Béguin \& J. Millet. Orlando: Academic Press.

Horikoshi, K., NaKao, M., Kurono, Y. \& Sashihara, N. (1984). Cellulases of an alkalophilic Bacillus strain isolated from the soil. Canadian Journal of Microbiology 30, 774-779.

Hunkapiller, M. W., Hewick, R. M., Dreyer, W. J. \& Hood, L. E. (1983). High-sensitivity sequencing with a gas-phase sequenator. Methods in Enzymology 91, 399-413.

Hurst, P. L., Sullivan, P. A. \& Shepherd, M. G. (1977). Chemical modification of a cellulase from Aspergillus niger. Biochemical Journal 167, 549-556.

Ito, S., Shikata, S., Ozaki, K., Kawai, S., OKamoto, K., Inove, S., TAKeI, A., Ohta, Y. \& SATOH, T. (1989). Alkaline cellulase for laundry detergents: production by Bacillus sp. KSM-635 and enzymatic properties. Agricultural and Biological Chemistry 53, 1275-1281.

Kawai, S., Okoshi, H., Ozaki, K., Shikata, S., Ara, K. \& Ito, S. (1988). Neutrophilic Bacillus strain, KSM-552, that produces an alkaline carboxymethyl cellulase. Agricultural and Biological Chemistry 52, 1425-1431.

KNösEL, D. (1971). Continued investigations for pectolytic and cellulolytic activity of different Bacillus species. Zentralblatt für Bacteriologie 126, 604-609.

LAEMMLI, U. K. (1970). Cleavage of structural proteins during the assembly of the head of bacteriophage T4. Nature, London 227, 680-685.

Mackay, R. M., Lo, A., Willick, G., Zuker, M., Baird, S., Dove, M., Moranelli, F. \& Seligy, V. (1986). Structure of a Bacillus subtilis endo- $\beta$-1,4-glucanase gene. Nucleic Acids Research 14, 9159-9170.

Miller, G. L., Blum, R., Glennon, W. E. \& Burton, A. L. (1960). Measurement of carboxymethylcellulase activity. Analytical Biochemistry 2, 127-132.

Nakamura, A., Uozumi, T. \& Beppu, T. (1987). Nucleotide sequence of a cellulase gene of Bacillus subtilis. European Journal of Biochemistry 164, 317-320.

Nakamura, K. \& Kitamura, K. (1983). Purification and some properties of a cellulase active on crystalline cellulose from Cellulomonas uda. Journal of Fermentation Technology 61, 379-382.

NG, T. K. \& ZEIKUS, J. G. (1981). Purification and characterization of an endoglucanase (1,4- $\beta$-D-glucan glucanohydrolase) from Clostridium thermocellum. Biochemical Journal 199, 341-350.

OAKLEY, B. R., KIRSCH, D. R. \& MORRIS, N. R. (1980). A simplified ultrasensitive silver stain for detecting proteins in polyacrylamide gels. Analytical Biochemistry 105, 361-363.

OKoshi, H., Ozaki, K., Shikata, S., Oshino, K., Kawai, S. \& Ito, S. (1990). Purification and characterization of multiple carboxymethyl cellulases from Bacillus sp. KSM-522. Agricultural and Biological Chemistry 54, 83-89.

Ozaki, K., Shikata, S., Kawai, S., Ito, S. \& Okamoto, K. (1990). Molecular cloning and nucleotide sequence of a gene for alkaline 
cellulase from Bacillus sp. KSM-635. Journal of General Microbiology 136, 1327-1334.

Pettersson, G. (1968). Structure and function of a cellulase from Penicillium notatum as studied by chemical modification and solvent accessibility. Archives of Biochemistry and Biophysics 126, 776-784.

Reisfeld, R. A., Lewis, U. J. \& Williams, D. E. (1962). Disk electrophoresis of basic proteins and peptides on polyacrylamide gels. Nature, London 195, 281-283.

Robson, L. M. \& Chambliss, G. H. (1984). Characterization of the cellulolytic activity of a Bacillus isolate. Applied and Environmental Microbiology 47, 1039-1046.

Robson, L. M. \& Chambliss, G. H. (1987). Endo- $\beta$-1,4-glucanase gene of Bacillus subtilis DLG. Journal of Bacteriology 169, 2017-2025.

SADDLER, J. N. \& KhAN, A. W. (1979). Cellulose degradation by a new isolate from sewage sludge, a member of the Bacteroidaceae family. Canadian Journal of Microbiology 25, 1427-1432.

SAdDler, J. N., Khan, A. W. \& MarTin, S. M. (1980). Regulation of cellulase synthesis in Acetivibrio cellulolyticus. Microbios 28, 97-106.

Shikata, S., Saeki, K., Okoshi, H., Yoshimatsu, T., Ozaki, K. KAWAI, S. \& ITO, S. (1990). Alkaline cellulases for laundry detergents: production by alkalophilic strains of Bacillus and some properties of the crude enzymes. Agricultural and Biological Chemistry 54, 91-96.

Sidhu, M. S., Kalra, M. K. \& Sandhu, D. K. (1986). Purification and characterization of cellulolytic enzymes from Trichoderma harzianum. Folia Microbiologica 31, 293-302.
Spande, T. F. \& WiTKOP, B. (1967). Determination of the tryptophan content of proteins with $\mathrm{N}$-bromosuccinimide. Methods in Enzymo$\log y$ 11, 498-506.

StOPPOK, W., RAPP, P. \& WAGNER, F. (1982). Formation, location, and regulation of endo-1,4- $\beta$-glucanases and $\beta$-glucosidases from Cellulomonas uda. Applied and Environmental Microbiology 44, 44-53.

TewarI, H. K. \& Chanal, D. S. (1977). Growth and cellulase formation by Bacillus sp. Indian Journal of Microbiology 17, 23-26.

THAYER, D. W. (1978). Carboxymethylcellulase produced by facultative bacteria from the hind-gut of the termite Reticulitermes hesperus. Journal of General Microbiology 106, 13-18.

Tomita, Y., SuzuKI, H. \& Nisizawa, K. (1974). Further purification and properties of "Avicelase", a cellulase component of less-random type from Trichoderma viride. Journal of Fermentation Technology 52, 233-246.

WRIGLEY, C. W. (1971). Gel electrofocusing. Methods in Enzymology 22, 559-564.

Wu, J. H. D., Orme-Johnson, W. H. \& Demain, A. L. (1988). Two components of an extracellular protein aggregate of Clostridium thermocellum together degrade crystalline cellulose. Biochemistry 27, 1703-1709.

Yoshimatsu, T., Ozaki, K., Shikata, S., Ohta, Y., Koike, K., Kawai, S. \& ITo, S. (1990). Purification and characterization of alkaline endo-1,4- $\beta$-glucanases from alkalophilic Bacillus sp. KSM-635. Journal of General Microbiology 136, 1973-1979. 